\title{
УДК 343.4:179.7]:343.8(438)
}

\author{
М. Ю. Шуп'яна ${ }^{1}$, \\ канд. юридичних наук, доцент \\ кафедри кримінального права i \\ кримінології юридичного факультету \\ Львівського національного \\ університету імені Івана Франка
}

\section{ЕВТАНАЗІЯ В РЕСПУБЛЦЦІ ПОЛЬЩА: КРИМІНАЛЬНО-ПРАВОВЕ РЕГУЛЮВАННЯ}

Стаття присвячена висвітленню сутності та змісту складу злочину передбаченого ст. 150 «Вбивство вчинене за допомогою евтаназії» Кримінального Кодексу Республіки Польща. Проаналізовано питання пов'язані із об'єктивними та суб'єктивними ознаками даного складу злочину та призначенням більш м'якого покарання та правом суду не призначати винній особі покарання. Автор акиентує увагу на тому, що визначення вбивства вчиненого за допомогою евтаназї, як привілейованого складу умисного вбивства враховує його особливості та відповідає принщипу справедливості.

Ключові слова: евтаназія, вимога, співчуття, фізичні страждання, психічні страждання.

Постановка проблеми та її зв'язок із практичними завданнями. За допомогою засобів масової інформації останнім часом слово «евтаназія» все частіше перебуває в центрі уваги не лише юристів та лікарів, а й пересічних громадян. Цей термін вперше було введено в обіг в XVII столітті англійським філософом Френсісом Беконом для визначення легкого безболісного відходу в небуття. «Евтаназія» - в перекладі з грецької (еиіпапазіа), означає «добра смерть», хоча, як свідчить історія, це було не завжди так. Враховуючи тенденцію до збільшення європейський країн у яких легалізовано евтаназію, Україні, що вийшла на міжнародну арену, необхідно бути готовою до вирішення цього питання. Право на життя людини є однією з основних, гарантованих Конституцією України, цінностей нашого суспільства на захист якої спрямована діяльність держави. Гарантуючи право на життя, про його якість не за-

\footnotetext{
${ }^{1}$ Фіналіст Всеукраїнського конкурсу малих грантів для молодих вчених у галузі кримінального права, кримінології та кримінально-виконавчого права.
} 
ведено замислюватися. Але, іноді право на життя трансформується в обов'язок людини жити. Життя людини завжди перебуває в динамічному розвитку і зазнає різноманітних змін. Протягом усього життя ми приймає різноманітні рішення, однак вирішення питання пов'язаного із останнім етапом життя смертю, є від нас незалежним. Водночас, як бачимо, як в Україні так і у деяких європейських державах, серед яких є і Республіка Польща, законодавець позбавив особу права вирішувати питання пов'язане із закінченням ï життя, бо навіть ії згода, прохання, а чи навіть вимога про позбавлення іiі життя не виключають наявності в діях винної особи кримінально-караного діяння. Тема евтаназії важлива, але водночас неоднозначна, подекуди і скандальна. Через нестачу правдивої інформації обростає страхами й домислами. Розбиратися в цьому питанні варто з холодною головою, озброївшись досвідом інших країн. Тут також необхідно згадати і позицію Європейського суду з прав людини який зазначає, що у питаннях стосовно закінчення життя державам слід надати можливість розсуду не лише щодо дозволу або заборони на припинення лікування, яке штучно підтримує життя, і супутніх формальностей, але й стосовно способу врівноваження захисту права на життя пацієнта і права на повагу до його приватного життя і особистої автономіїㄹ․ Вищенаведене, а також процеси євроінтеграції, свідчать про актуальність даного питання у руслі дослідження європейського досвіду, що є важливим аспектом якнайкращого вирішення даного питання у нашому законодавстві.

Аналіз останніх досліджень та публікацій. Теоретичним і практичним проблемами пов'язаними із питанням кримінальної відповідальності за вбивство вчинене за допомогою евтаназії приділялась увага у роботах відомих зарубіжних вчених в галузі кримінального права, зокрема, А. Бздик, К. Дашкевич, А. Золь, Р. Краєвський, А. Марек, М. Мозгава, Р. Цітович та ін., які проаналізували та розвинули існуючі наукові уявлення з цього питання.

\footnotetext{
2 Дроздов О. Чи має людина право на смерть - позиція ЄСПЛ. Закон і бізнес. 2020. 27 лютого. URL: https://zib.com.ua/ua/141629-chi_mae_lyudina_pravo_na_smert_poziciya_espl.html (дата звернення: 26.03.2020).
} 
Однак, не зважаючи на вказане, необхідно зазначити, що у сучасній юридичній літературі з кримінального права, мають місце поки що початкові спроби дослідження питання пов'язаного із порівняльно-правовим досвідом у сфері криміналізації евтаназії, тому даний аспект цього питання поки що залишається його невирішеною частиною. Саме тому, метою статті є детальний аналіз чинного законодавства і юридичної літератури, а також подальша розробка питання пов'язаного із питанням кримінальної відповідальності за евтаназію в Республіці Польща.

Виклад основного матеріалу. Про право людини закінчити свій життєвий шлях гідно давно говорять у багатьох куточках нашої планети, проте, законодавчо дозволити евтаназію зважилися тільки деякі країни. Втім, їх список з кожним роком зростає. Говорячи юридичною мовою, правове забезпечення позбавлення життя іншої людини на ії прохання в різних формах евтаназія, ортаназія, САЛ (самогубство, асистоване лікарем) - закріплене в Голландії, Бельгії, Франції, Ізраїлі, Канаді, Швейцарії та деяких штатах США (Орегон, Вашингтон, Монтана, Вермонт, Каліфорнія). Широкі дебати про легалізацію евтаназії (або САЛ) ведуться у Великій Британії, Греції, Італії, Іспанії, Росії. Деякі країни, такі як Грузія, Данія, Молдова, Польща, як альтернативу виділили окремий привілейований склад злочину - вбивство 3 жалю ${ }^{3}$. Отже, зупинимось на останній групі країн, зокрема на досвіді Республіки Польща.

Кримінальна відповідальність за вбивство вчинене за допомогою евтаназії передбачена у ст. 150 чинного кримінального кодексу Республіки Польща (далі КК РП), зміст якої відповідає змісту ст. 150 кримінального кодексу 1969 р. та ст. 227 кримінального кодексу 1932 р. Отже, як бачимо, такий склад злочину не $\epsilon$ новим для польського кримінального права. Щодо змісту згаданих статей, то відмінність між ними є лише у санкції, а їх диспо-

\footnotetext{
${ }^{3}$ Шклярська О. Евтанзія: «хороша смерть», вбивство, акт милосердя чи право людини? URL: https://racurs.ua/ua/2228-v-ukrayini-zagovoryly-pro-evtanaziu-horosha-smert-vbyvstvo-akt-myloserdya-chy-pravoludyny.html (дата звернення: 26.03.2020).
} 
зиція, водночас і склад злочину, змін не зазнав. Що ж до змісту диспозиції, то у ст. 227 кримінального кодексу 1932 р. було передбачено, що вбивство особи на ії вимогу та вчинене під впливом співчуття до неї карається позбавленням волі до п'яти років або арештом‥ У обгрунтуванні кодифікаційної комісії, щодо сутності даного складу злочину зазначалось, що така вимога повинна бути зовнішньо вираженим безсумнівним бажанням особи. Її зміст та форма повинні чітко виражати їі бажання померти та бути переконливими. У доктрині польського кримінального права підкреслювалось, що про вбивство вчинене за допомогою евтаназії можна говорити лише тоді особа вважає смерть визволенням від більшого зла яке ії очікує, якщо вона залишиться живою, у зв'язку з тим, що вона хвора на невиліковну хворобу, яка супроводжується довготривалим нестерпним болем. Однак окрім вимоги для даного складу злочину є характерним і його мотив - співчуття до потерпілої особи. Якщо ж даний мотив був відсутнім, то особа притягалась до кримінальної відповідальності за умисне вбивство 5 . У кримінальному кодексі 1969 р. диспозиція статті про вбивство вчинене за допомогою евтаназії (ст. 150 даного кодексу) була ідентична вищезазначеній диспозиції ст. 227 кодексу 1932 р Однак необхідно наголосити, що з 1970 р. по 1980 р. судом було винесено лише сім обвинувальних вироків по даній статті ${ }^{7}$.

Що ж стосується чинного кримінального кодексу Республіки Польща від 6 червня 1997 р. то питання пов'язане із вбивством, вчиненим за допомогою евтаназії, врегульоване, як вже зазначалось вище, ст. 150 у якій диспозиція, як і в іï попередніх редакціях 1932 р. та 1969 р. сформульована: «хто вб'є

\footnotetext{
${ }^{4}$ Kodeks karny z dnia 11 lipca 1932 r. / Sejm Rzeczpospolitej Polski. URL: http://prawo.sejm. gov.pl/isap.nsf/DocDetails.xsp?id=WDU19320600571 (дата звернення: 26.03.2020).

${ }^{5}$ Mozgawa-Saj M. Eutanazja w polskim prawie karnym. URL: file:///C:/Users/\%D0\%90\%D0\%B4\% D0\%BC\%D0\%B8\%D0\%BD\%D0\%B8\%D1\%81\%D1\%82\%D1\%80\%D0\%B0\%D1\%82\%D0\%BE\%D1\%80/Downl oads/1471-5927-1-РВ\%20(1).pdf (дата звернення: 26.03.2020).

${ }^{6}$ Kodeks karny z dnia 19 kwietnia 1969 r. / Sejm Rzeczpospolitej Polski. URL: http://prawo.sejm.gov. pl/isap.nsf/DocDetails.xsp?id=WDU19690130094 (дата звернення: 26.03.2020).

${ }^{7}$ Mozgawa-Saj M. Eutanazja w polskim prawie karnym. URL: file:///C:/Users/\%D0\%90\%D0\%B4\% D0\%BC\%D0\%B8\%D0\%BD\%D0\%B8\%D1\%81\%D1\%82\%D1\%80\%D0\%B0\%D1\%82\%D0\%BE\%D1\%80/Downl oads/1471-5927-1-РВ\%20(1).pdf (дата звернення: 26.03.2020).
} 
особу на ï вимогу та під впливом співчуття до неї». Однак новелою є ч. 2 ст. 150 у якій зазначається, що у виняткових випадках суд має право призначити більш м'яке покарання ніж передбачено даною статтею або й навіть не призначати винній особі покарання ${ }^{8}$. Як зазначалось в обгрунтуванні до проєкту чинного кримінального кодексу 1997 р., поданого урядом: «питання пов'язане із сутністю вбивства вчиненого за допомогою евтаназії не потребує змін у порівнянні із кодексом 1932 р. Передбачення м'якшого покарання за дане діяння пов'язане із меншим ступенем вини. Незважаючи те, що таке діяння не є кримінально-караним у багатьох державах уряд виступає проти його декриміналізації, а також виступає за недоторканість життя, як найвищої цінності» 9.

Отже, згідно з ч. 1 ст. 150 КК РП, щоб діяння особи можна було кваліфікувати, як вбивство вчинене за допомогою евтаназії, має бути дві умови:

1) вимога потерпілої особи;

2) мотив співчуття.

Щодо першої умови, то така вимога повинна бути чіткою, однозначною та вільною. Вона не може бути здійснена внаслідок примусу, а повинна бути результатом власного рішення, яке повинно бути остаточним, реальним, чітко вираженим та переконливим, висловленим особою, яка вважає смерть визволенням від болю, який вона терпить. Це повинна бути вимога про негайну смерть, вона не може бути пов'язана із будь-якими умовами чи обставинами, які матимуть місце у майбутньому. Висловити таку вимогу може лише особа, яка здатна оцінити сутність життєвої ситуації в якій вона перебуває та зміст прийнятого нею рішення ${ }^{10}$. Не може бути потерпілим у даному складі злочину особа яка має розумову відсталість, психічну хворобу чи ін-

\footnotetext{
${ }^{8}$ Kodeks karny Rzeczpospolitej Polski z dnia 6 czerwca 1997 r. / Sejm Rzeczpospolitej Polski. URL: http://prawo.sejm.gov.pl/isap.nsf/download.xsp/WDU19970880553/U/D19970553Lj.pdf (дата звернення: 26.03.2020).

${ }^{9}$ Jaroszewska A. Zabójstwo eutanatyczne w polskim prawie karnym. URL: https://wpia.uwm.edu.pl/ czasopisma/sites/default/files/uploads/KPP-Monografie/4/ 65-72.pdf (дата звернення: 26.03.2020).

${ }^{10}$ Daszkiewicz K. Przestępstwa przeciwko życiu i zdrowiu. Rozdział XIX kodeksu karnego. Komentarz. Warszawa, 2000. S. 467.
} 
ший розлад психіки, що виключає можливість усвідомлювати свої рішення. Також потерпілим у цьому складі злочину не може бути особа, яка перебуває у стані нервового зриву, а також у стані алкогольного чи наркотичного сп'яніння чи неповнолітня особа. В цьому випадку таке вбивство не може бути кваліфікованим за даною статтею, тобто не $є$ привілейованим складом злочину, а повинно бути кваліфіковане, як просте умисне вбивство, за ст. 148 КК РП ${ }^{11}$. Також, як зазначає Апеляційний суд у місті Вроцлав у своєму вироку від 19 грудня 2014 р.: «вимога на відміну від згоди чи прохання, пов'язана із елементом тиску на психіку iї адресата. Ініціатива має виходити саме від особи, яка висловлює вимогу, а не від іiі адресата» ${ }^{12}$. Також необхідно зазначити, що вимога особи про позбавлення іiі життя в жодному випадку не може бути обставиною, що виключає злочинність діяння, а лише підставою для кваліфікації діяння особи за ст. 150 КК РП, яка містить привілейований склад умисного вбивства.

Більш дискусійним $є$ питання пов'язане із змістом другої умови - мотиву співчуття. У доктрині домінуючим є погляд згідно з яким підставою для співчуття можуть бути лише фізичні страждання невиліковно хворої особи. Що ж стосується психічних страждань, то вони є відокремленим від фізичних i не враховуються для визначення мотиву співчуття ${ }^{13}$. Такий висновок підтверджується позицією Верховного Суду висловленою у вироку від 1936 р. у якому він зазначив, що співчуття матиме місце лише в тому випадку, якщо винна особа є переконана в тому, що, особа, яка просить іiї про смерть терпить такий сильний біль, що дивлячись на іiї терпіння смерть для неї є добро-

\footnotetext{
${ }^{11}$ Bzdyk A. Aborcja i eutanazja w polskim prawie karnym - wybrane zagadnienia. URL: file:///C:/Users/\%D0\%90\%D0\%B4\%D0\%BC\%D0\%B8\%D0\%BD\%D0\%B8\%D1\%81\%D1\%82\%D1\%80\%D0\%B0 $\% \mathrm{D} 1 \% 82 \% \mathrm{D} 0 \% \mathrm{BE} \% \mathrm{D} 1 \% 80 / \mathrm{Downloads} / 08-\mathrm{BZDYK} \% 20(2)$.pdf (дата звернення: 26.03.2020).

${ }^{12}$ Wyrok Sądu Apelacyjnego we Wrocławiu z dnia 19 grudnia 2014 r. (sygn. akt II AKa 267/14). URL: http://orzeczenia.wroclaw.sa.gov.pl/content/\$N/155000000001006_II_AKa_000267_2014_Uz_2014-12-19_001 (дата звернення: 26.03.2020).

${ }^{13}$ Sobczak J. Kodeks karny. Komentarz / red. R. Stefański. Warszawa, 2015. S. 654.
} 
дійством і може позбавити її від цих терпінь ${ }^{14}$. Даний висновок знаходить свій вияв і у судовій практиці. Зокрема, Апеляційний суд у місті Лодзь у своєму вироку від 6 серпня 2013 р. зазначив, що даний склад злочину буде відсутнім у випадку коли співчуття викликане психічними стражданнями пов'язаними із матеріальним станом, нерозділеним коханням чи довготривалою інвалідністю, а також коли воно стосується іншої особи чи осіб аніж потерпілий $^{15}$. Також, як зазначається у вже згаданому вище вироку Апеляційного суду у місті Вроцлав від 19 грудня 2014 р.: «Вбивство особи на ії вимогу не може бути кваліфікованим за ст. 150 КК РП, якщо мотивом винної особи було інше почуття аніж співчуття до потерпілої особи, оскільки у такому випадку є відсутня суб'єктивна сторона даного складу злочину» ${ }^{16}$. Однак необхідно зазначити, що кодекс не обмежує підставу виникнення мотиву співчуття лише до фізичного терпіння від невиліковної хвороби. До прикладу А. Марек зазначає, що такою підставою можуть бути також і тяжкі тілесні ушкодження отримані внаслідок катастрофи чи вибуху (наприклад потерпілий має відірвану верхню чи нижню кінцівку, ушкодження голови чи втратив зір), які $є$ причиною вимоги про позбавлення ії життя. Розширити дане коло підстав пропонує М. Цесляк, який зазначає, що не має жодної підстави для виключення з їх кола психічних страждань (наприклад вимога пов'язана із втратою близької особи чи нерозділеним коханням) ${ }^{17}$. Однак необхідно наголосити, що склад злочину передбачений ст. 150 КК РП буде відсутнім, якщо вимоги про позбавлення життя від потерпілої особи не було, однак винний діяв із мотивів співчуття. Визначення мотиву співчуття потребує детального аналізу

\footnotetext{
${ }^{14}$ Jaroszewska A. Zabójstwo eutanatyczne w polskim prawie karnym. URL: https://wpia.uwm.edu.pl/ czasopisma/sites/default/files/uploads/KPP-Monografie/4/ 65-72.pdf (дата звернення: 26.03.2020).

${ }^{15}$ Wyroku z dnia 6 sierpnia 2013 r. Sąd Apelacyjny w Łodzi (sygn. akt II Aka 118/13). URL: http://orzeczenia.lodz.sa.gov.pl/content/\$N/ 152500000001006_II_AKa_000118_2013_Uz_2013-08-06_001 (дата звернення: 26.03.2020).

${ }^{16}$ Wyrok Sądu Apelacyjnego we Wrocławiu z dnia 19 grudnia 2014 r. (sygn. akt II AKa 267/14). URL: http://orzeczenia.wroclaw.sa.gov.pl/content/\$N/155000000001006_II_AKa_000267_2014_Uz_2014-12-19_001 (дата звернення: 26.03.2020).

${ }^{17}$ Mozgawa-Saj M. Eutanazja w polskim prawie karnym. URL: file:///C:/Users/\%D0\%90\%D0\%B4\% D0\%BC\%D0\%B8\%D0\%BD\%D0\%B8\%D1\%81\%D1\%82\%D1\%80\%D0\%B0\%D1\%82\%D0\%BE\%D1\%80/Downl oads/1471-5927-1-PB\%20(1).pdf (дата звернення: 26.03.2020).
} 
у кожній конкретній ситуації усіх деталей, зокрема, стану здоров'я потерпілої особи та винного, а також емоційний зв'язок між винним і потерпілим, а не лише способу вчинення даного злочину, який аж ніяк не може слугувати основою для побудови єдиної моделі для визначення наявності чи відсутності даного мотиву ${ }^{18}$.

Вбивство вчинене за допомогою евтаназії з об'єктивної сторони може бути вчинене, як шляхом дії так і бездіяльності. Щодо бездіяльності, тобто невиконання дії, яку особа мала обов'язок вчинити, то найчастіше вона полягає у ненаданні особі ліку, який необхідний для підтримання іiі життя. У даному аспекті доречно звернути увагу і на питання наявності складу злочину передбаченого ст. 150 КК РП у випадку коли бездіяльність полягає у невиконанні обов'язку підтримання життя особи за допомогою спеціальної апаратури. У ситуації, коли це стосується непритомної особи, яка не може виразити своєї волі щодо продовження свого життя чи вимагати смерті і перебуває у важкому стані, а також в неї підтверджено смерть мозку, при збереженні газообміну та серцевої діяльності, які забезпечуються безперервною штучною вентиляцією легень і подальше підтримання її у такому стані не дасть жодного результату, то відключення іiі від апарату штучного дихання не буде кримінально-караним ${ }^{19}$. Що до моменту 3 якого даний злочин вважається закінченим, то необхідно наголосити, що склад злочину передбачений ст. 150 КК РП є злочином із матеріальним складом, оскільки моментом його закінчення є смерть особи, яка вимагала позбавити ії життя.

Даний злочин відноситься до злочинів із загальним суб'єктом. Тому суб'єктом даного злочину може бути будь-яка особа, яка наділена всіма ознаками суб'єкта злочину, а не лише медичні працівники. Однак, у випадку, коли такий злочин був вчинений шляхом бездіяльності, то відповідно до ст. 2 КК РП суб'єктом даного злочину може бути лише та особа на яку, згідно із при-

\footnotetext{
${ }^{18}$ Daszkiewicz K. Przestępstwa przeciwko życiu i zdrowiu. Rozdział XIX kodeksu karnego. Komentarz. Warszawa, 2000. S. 468.

${ }^{19}$ Kodeks karny. Komentarz / Wydanie 8; redactor Marek Mozgawa. Warszawa, 2017. S. 495-496.
} 
писами законодавства було покладено обов'язок вчинити дії пов'язані із запобіганням наслідку у вигляді смерті особи ${ }^{20}$.

Що ж стосується суб'єктивної сторони вбивства вчиненого за допомогою евтаназії, то даний склад злочину може бути вчинений лише умисно. Однак, у доктрині польського кримінального права дискутується питання про те, чи даний злочин вчиняється лише $з$ прямим умислом, а чи може бути вчиненим і $з$ непрямим умислом. Як зазначає К. Дашкевич злочин передбачений ст. 150 КК РП може бути вчинений, як з прямим так і з непрямим умислом. Такої ж позиції дотримуються і А. Марек і М. Цесляк. Як зазначає А. Марек непрямий умисел може мати місце, наприклад, у випадку коли винна особа керуючись мотивом співчуття та погоджуючись на вимогу потерпілої особи та не те, що наслідком його дій може стати смерть потерпілої особи дає їй таку кількість лікарського засобу, яка $\epsilon$ небезпечною. Однак А. Золь та Я. Слівовський зазначають, що цей злочин може бути вчинений лише 3 прямим умислом. Як зазначає А. Золь підтвердженням того, що злочин, передбачений ст. 150 КК РП, може бути вчинений лише з прямим умислом є його специфічний мотив - мотив співчуття до потерпілого. Метою такого вбивства є припинення страждань особи, яка вимагає позбавити їі життя. Такої ж позиції дотримується і Я. Слівовський, який наголошує на тому, що мотив є обов'язковою ознакою суб'єктивної сторони складу злочину передбаченого ст. 150 КК РП, що виключає можливість його вчинення 3 непрямим умислом $^{21}$. Однак, як зазначає М. Мозгава-Сай, позицію якої ми цілком підтримуємо, аналіз об'єктивної сторони даного складу злочину свідчить про те, що не має жодних перепон для того, щоб цей злочин було вчинено із непрямим умислом, оскільки мотивація згідно із доктриною польського кримінального

\footnotetext{
${ }^{20}$ Mozgawa-Saj M. Eutanazja w polskim prawie karnym. URL: file:///C:/Users/\%D0\%90\%D0\%B4\% D0\%BC\%D0\%B8\%D0\%BD\%D0\%B8\%D1\%81\%D1\%82\%D1\%80\%D0\%B0\%D1\%82\%D0\%BE\%D1\%80/Downl oads/1471-5927-1-PB\%20(1).pdf (дата звернення: 26.03.2020).

${ }^{21}$ Jaroszewska A. Zabójstwo eutanatyczne w polskim prawie karnym. URL: https://wpia.uwm.edu.pl/ czasopisma/sites/default/files/uploads/KPP-Monografie/4/ 65-72.pdf (дата звернення: 26.03.2020).
} 
права не є визначальною для встановлення того факту, що злочин може бути вчинений лише 3 прямим умислом 22 .

Аналізуючи даний склад злочину необхідно звернути свою увагу і на питання співвідношення між вбивством вчиненим за допомогою евтаназії та злочину передбаченого ст. 192 КК РП (проведення лікування без згоди пацієнта). У цьому випадку необхідно звернутись, як зазначається у доктрині польського кримінального права, до стану крайньої необхідності (ст. 26 КК РП). Також виникає питання про співвідношення ст. 150 КК РП та ст. 151 КК РП (доведення до самогубства). У цій ситуації питання, яку ж статтю застосувати вирішуватиметься за допомогою вже згаданого вище мотиву співчуття, оскільки він є притаманним лише ст. 150 КК РП і його присутність бути свідчити про наявність в діянні особи саме даного складу злочину. Цікавим у цьому аспекті є питання, а чи відповідатиме лікар, який перевищив дозу обезболюючих ліків. Як зазначають П. Гуральський та Е. Зелінська лікар нестиме відповідальність за такі дії, враховуючи приписи Закону про заклади охорони здоров'я та Кодексу Лікарської Етики, лише у випадку, якщо таке перевищення не відповідало рівню болю особи ${ }^{23}$.

Як уже згадувалось вище новелою законодавчого регулювання питання пов'язаного із вбивством вчиненим за допомогою евтаназії є ч. 2 ст. 150 у якій зазначається, що у виняткових випадках суд має право призначити більш м'яке покарання ніж передбачено даною статтею або й навіть не призначати винній особі покарання. До таких виняткових випадків, у доктрині польського кримінального права, відносять особливо сильний тиск на винну особу мотиву співчуття до потерпілого, а також виправдані причини такого спів-

\footnotetext{
${ }^{22}$ Mozgawa-Saj M. Eutanazja w polskim prawie karnym. URL: file:///C:/Users/\%D0\%90\%D0\%B4\% D0\%BC\%D0\%B8\%D0\%BD\%D0\%B8\%D1\%81\%D1\%82\%D1\%80\%D0\%B0\%D1\%82\%D0\%BE\%D1\%80/Downl oads/1471-5927-1-PB\%20(1).pdf (дата звернення: 26.03.2020).

${ }^{23}$ Daszkiewicz K. Przestępstwa przeciwko życiu i zdrowiu. Rozdział XIX kodeksu karnego. Komentarz. Warszawa, 2000. S. 468-469.
} 
чуття $^{24}$. Як зазначає К. Дашкевич винятковий випадок може мати місце і тоді коли є особливо високий рівень інтенсивності терпіння особи, яка вимагає позбавити їі життя. Необхідно також брати до уваги і той факт, що винна особа діяла не лише під впливом співчуття, але і великої любові до особи, яку він бажає позбавити від нелюдських терпінь ${ }^{25}$. Що ж стосується права суду не призначати винній особі покарання, то необхідно наголосити, що в цьому випадку особа визнається винною у вчиненні даного злочину, а вирок є обвинувальним. Окрім покарання суд, на підставі ч. 2 ст. 150 КК РП, може також не призначати особі і кримінально-правового заходу, навіть якщо згідно із ч. 2 ст. 61 КК РП його призначення є обов'язковим ${ }^{26}$. У даному аспекті також важливо звернути увагу і на статистичні дані. Як свідчать статистичні дані наведені Міністерством юстиції Республіки Польща, кількість вироків винесених судами за вчинення даного злочину є надто мізерною, зокрема, 3 2000 р. по 2016 р. до суду було подано 77 справ, обвинувальним вироком 3 яких завершились лише чотири справи ${ }^{27}$.

Висновки. Питання пов'язане із вбивством вчиненим за допомогою евтаназії має комплексний та доволі дискусійний характер. Криміналізація даного діяння у польському кримінальному праві обгрунтовується та пов'язана із визнанням життя людини, як основної цінності, яка охороняється державою не лише, як право кожної особи, а й, як найвища соціальна цінність. У зв'язку з цим охорона життя особи не залежить від того чи вона здатна принести якусь користь суспільству чи ні, а також у особи є відсутньою необмежена можливість розпоряджатися своїм життям. Однак з іншої сторони ми не повинні забувати про особливість даного виду вбивства, що пов'язана із його

\footnotetext{
${ }^{24}$ Mozgawa-Saj M. Eutanazja w polskim prawie karnym. URL: file:///C:/Users/\%D0\%90\%D0\% B4\%D0\%BC\%D0\%B8\%D0\%BD\%D0\%B8\%D1\%81\%D1\%82\%D1\%80\%D0\%B0\%D1\%82\%D0\%BE\%D1\%80/D ownloads/1471-5927-1-РB\%20(1).pdf (дата звернення: 26.03.2020).

${ }^{25}$ Jaroszewska A. Zabójstwo eutanatyczne w polskim prawie karnym. URL: https://wpia.uwm.edu.pl/ czasopisma/sites/default/files/uploads/KPP-Monografie/4/ 65-72.pdf (дата звернення: 26.03.2020).

${ }^{26}$ Kodeks karny. Komentarz / Wydanie 8; redactor Marek Mozgawa. Warszawa, 2017. S. 496.

${ }^{27}$ Eutanazja (art. 150 KK RP). Statystyka 1999-2017 rr. URL: http://statystyka.policja.pl/st/kodekskarny/przestepstwa-przeciwko/63419,Eutanazja-art-150.html (дата звернення: 26.03.2020).
} 
моральним аспектом та із сприйняттям суспільством такого вбивства, а також оцінки ним терпіння потерпілого, співчуттям і смертю, як його наслідком. Законодавець, як видається побачив «винятковий» характер вбивства вчиненого за допомогою евтаназії та відніс його до привілейованих складів умисного вбивства, що до того ж, відповідає принципу справедливості, що має не аби яке значення для кримінального права.

\section{Список використаних джерел}

1. Bzdyk A. Aborcja i eutanazja w polskim prawie karnym - wybrane zagadnienia. URL: file:///C:/Users/\%D0\%90\%D0\%B4\%D0\%BC\%D0\%B8\%D0 \%BD\%D0\%B8\%D1\%81\%D1\%82\%D1\%80\%D0\%B0\%D1\%82\%D0\%BE\%D1\% 80/Downloads/08-BZDYK\%20(2).pdf (дата звернення: 26.03.2020).

2. Daszkiewicz K. Przestępstwa przeciwko życiu i zdrowiu. Rozdział XIX kodeksu karnego. Komentarz. Warszawa, 2000. 746 s.

3. Eutanazja (art. 150 KK RP). Statystyka 1999-2017 rr. URL: http://statystyka.policja.pl/st/kodeks-karny/przestepstwa-

przeciwko/63419,Eutanazja-art-150.html (дата звернення: 26.03.2020).

4. Jaroszewska A. Zabójstwo eutanatyczne w polskim prawie karnym. URL: $\quad$ https://wpia.uwm.edu.pl/czasopisma/sites/default/files/uploads/KPPMonografie/4/65-72.pdf (дата звернення: 26.03.2020).

5. Kodeks karny Rzeczpospolitej Polski z dnia 6 czerwca 1997 r. / Sejm Rzeczpospolitej Polski. URL: http://prawo.sejm.gov.pl/isap.nsf/download.xsp/ WDU19970880553/U/D19970553Lj.pdf (дата звернення: 26.03.2020).

6. Kodeks karny z dnia 11 lipca 1932 r. / Sejm Rzeczpospolitej Polski. URL: http://prawo.sejm.gov.pl/isap.nsf/DocDetails.xsp?id=WDU19320600571 (дата звернення: 26.03.2020).

7. Kodeks karny z dnia 19 kwietnia 1969 r. / Sejm Rzeczpospolitej Polski. URL: http://prawo.sejm.gov.pl/isap.nsf/DocDetails.xsp?id=WDU19690130094 (дата звернення: 26.03.2020).

8. Kodeks karny. Komentarz / Wydanie 8; redactor Marek Mozgawa. Warszawa, 2017. $1049 \mathrm{~s}$.

9. Mozgawa-Saj M. Eutanazja w polskim prawie karnym. URL: file://C:/Users/\%D0\%90\%D0\%B4\%D0\%BC\%D0\%B8\%D0\%BD\%D0\%B8\%D1 $\% 81 \% \mathrm{D} 1 \% 82 \% \mathrm{D} 1 \% 80 \% \mathrm{D} 0 \% \mathrm{~B} 0 \% \mathrm{D} 1 \% 82 \% \mathrm{D} 0 \% \mathrm{BE} \% \mathrm{D} 1 \% 80 /$ Downloads/14715927-1-PB\%20(1).pdf (дата звернення: 26.03.2020).

10. Sobczak J. Kodeks karny. Komentarz / red. R. Stefański. Warszawa, $2015.1468 \mathrm{~s}$. 
11. Wyrok Sądu Apelacyjnego we Wrocławiu z dnia 19 grudnia $2014 \mathrm{r}$. (sygn. akt II AKa 267/14). URL: http://orzeczenia.wroclaw.sa.gov.pl/content/\$N/ 155000000001006_II_AKa_000267_2014_Uz_2014-12-19_001 (дата звернення: 26.03.2020).

12. Wyroku z dnia 6 sierpnia 2013 r. Sąd Apelacyjny w Lodzi (sygn. akt II Aka 118/13). URL: http://orzeczenia.lodz.sa.gov.pl/content/\$N/ 152500000001006_II_AKa_000118_2013_Uz_2013-08-06_001 (дата звернення: 26.03.2020).

13. Дроздов О. Чи має людина право на смерть - позиція ССПЛ. Закон $i$ бізнес. 2020. 27 лютого. URL: https://zib.com.ua/ua/141629-chi_mae_ lyudina_pravo_na_smert_poziciya_espl.html (дата звернення: 26.03.2020).

14. Шклярська О. Евтанзія: «хороша смерть», вбивство, акт милосердя чи право людини? URL: https://racurs.ua/ua/2228-v-ukrayini-zagovoryly-proevtanaziu-horosha-smert-vbyvstvo-akt-myloserdya-chy-pravo-ludyny.html (дата звернення: 26.03.2020).

\section{REFERENCES}

1. Bzdyk, A. (2018). Aborcja i eutanazja w polskim prawie karnym wybrane zagadnienia. URL: file:///C:/Users/\%D0\%90\%D0\%B4\%D0\%BC\%D0 \%B8\%D0\%BD\%D0\%B8\%D1\%81\%D1\%82\%D1\%80\%D0\%B0\%D1\%82\%D0\% BE\%D1\%80/Downloads/08-BZDYK\%20(2).pdf [in Polish].

2. Daszkiewicz, K. (2000). Przestępstwa przeciwko życiu i zdrowiu. Rozdział XIX kodeksu karnego. Komentarz. Warszawa [in Polish].

3. Eutanazja (art. 150 KK RP). Statystyka 1999-2017 rr. (2018). URL: http://statystyka.policja.pl/st/kodeks-karny/przestepstwa-przeciwko/63419, Eutanazja-art-150.html [in Polish].

4. Jaroszewska, A. (2019). Zabójstwo eutanatyczne w polskim prawie karnym. URL: https://wpia.uwm.edu.pl/czasopisma/sites/default/files/uploads/ KPP-Monografie/4/ 65-72.pdf [in Polish].

5. Kodeks karny Rzeczpospolitej Polski z dnia 6 czerwca 1997 r. (1997). URL: $\quad$ http://prawo.sejm.gov.pl/isap.nsf/download.xsp/WDU19970880553/U/ D19970553Lj.pdf [in Polish].

6. Kodeks karny z dnia 11 lipca 1932 r. (1932). URL: http://prawo. sejm.gov.pl/isap.nsf/DocDetails.xsp?id=WDU19320600571 [in Polish].

7. Kodeks karny z dnia 19 kwietnia 1969 r. (1969). URL: http://prawo. sejm.gov.pl/isap.nsf/DocDetails.xsp?id=WDU19690130094 [in Polish].

8. Kodeks karny. Komentarz (2017). Marek Mozgawa (Ed.). Warszawa [in Polish].

9. Mozgawa-Saj, M. (2015). Eutanazja w polskim prawie karnym. URL: file://C:/Users/\%D0\%90\%D0\%B4\%D0\%BC\%D0\%B8\%D0\%BD\%D0\%B8\%D1 $\% 81 \% \mathrm{D} 1 \% 82 \% \mathrm{D} 1 \% 80 \% \mathrm{D} 0 \% \mathrm{~B} 0 \% \mathrm{D} 1 \% 82 \% \mathrm{D} 0 \% \mathrm{BE} \% \mathrm{D} 1 \% 80 /$ Downloads/14715927-1-PB\%20(1).pdf [in Polish]. 
10. Sobczak, J. (2015). Kodeks karny. Komentarz. R. Stefański (Ed). Warszawa [in Polish].

11. Wyrok Sądu Apelacyjnego we Wrocławiu z dnia 19 grudnia 2014 r. (sygn. akt II AKa 267/14). (2014). URL: http://orzeczenia.wroclaw.sa.gov.pl/ content/\$N/155000000001006_II_AKa_000267_2014_Uz_2014-12-19_001 [in Polish].

12. Wyroku z dnia 6 sierpnia 2013 r. Sąd Apelacyjny w Lodzi (sygn. akt II Aka 118/13). (2013). URL: http://orzeczenia.lodz.sa.gov.pl/content/\$N/ 152500000001006_II_AKa_000118_2013_Uz_2013-08-06_001 [in Polish].

13. Drozdov, O. (2020). Chy maye lyudyna pravo na smert' - pozytsiya YESPL. Zakon i biznes, 27 lyutoho. URL: https://zib.com.ua/ua/141629-chi_mae_ lyudina_pravo_na_smert_poziciya_espl.html [in Ukrainian].

14. Shklyars'ka, O. (2019). Evtanziya: «khorosha smert'», vbyvstvo, akt myloserdya chy pravo lyudyny? URL: https://racurs.ua/ua/2228-v-ukrayinizagovoryly-pro-evtanaziu-horosha-smert-vbyvstvo-akt-myloserdya-chy-pravoludyny.html [in Ukrainian].

\section{Шупьяна М. Ю. Эвтаназия в Республике Польща: уголовно-правовое} регулирование

Статья посвящена освещению сущности и содержания состава преступления предусмотренного ст. 150 «Убийство совершенное с помощью эвтаназии» Уголовного Кодекса Республики Польша. Проанализированы вопросы, связанные с объективными и субъективными признаками данного состава преступления и назначением более мягкого наказания и правом суда не назначать виновному лииу наказания. Автор акцентирует внимание на том, что определение убийства совершенного с помощью эвтаназии, как привилегированного состава умышленного убийства учитывает его особенности и соответствует принципу справедливости.

Ключевые слова: эвтаназия, требование, сострадание, физические страдания, психические страдания.

\section{Shupyana M. Yu. Euthanasia in the Republic of Poland: criminal and legal regulation}

Article is devoted to the nature and content of the crime under art. 150 «Murder by euthanasia» of the Criminal Code of the Republic of Poland. Analyzed issues related with objective and subjective features composition of this crime and the appointment of more lenient punishment and the right of the court not to impose punishment on the guilty person. It is noted that the right of the court not to impose punishment on the guilty person for this crime is a novelty of the legal regulation of liability for this criminal offense. This right may be exercised only in exceptional cases. Such exceptional cases, in the doctrine of Polish criminal law, include particularly strong pressure on the perpetrator of the motive of compassion for the victim, as well as justified reasons for such compassion. It is emphasized 
that this crime refers to crimes with a common subject. Therefore, the subject of this crime can be any person who is endowed with all the characteristics of the subject of the crime, not just medical professionals. However, in the case where such a crime was committed by inaction, in accordance with Art. 2 of the Criminal Code of the Republic of Poland, the subject of this crime can only be a person who, in accordance with the provisions of the law was obliged to take action to prevent the consequences in the form of death. It has been found that, on the subjective side, murder by euthanasia can only be committed intentionally. However, the doctrine of Polish criminal law discusses the question of whether a crime is committed only with direct intent, and whether it can be committed with indirect intent. The author emphasizes that the definition of murder by euthanasia as a privileged composition of premeditated murder takes into account its peculiarities, elated to its moral aspect and society's perception of such murder, as well as its appreciation of the victim's suffering, compassion and death as a consequence and meets the principle of justice.

Key words: euthanasia, requirement, compassion, physical suffering, mental suffering. 